special interest at the moment. Emphasizing the importance of scientific work in this field, he suggests that in it lie the possibilities of ultimate social intelligence. Social progress more and more requires minds trained to function scientifically on social problems, as well as improved facilities for observing, recording and interpreting social phenomena and public recognition of the importance of accessions of knowledge in this field. The appropriations of the Foundation in this field in 1937 were largely for the promotion of research in social security, international relations, and public administration. It is satisfactory to note that although the normal development of the work in China has been rudely interrupted, no project has been discontinued, although six out of the eight major projects have been forced to leave the areas in which their work was being done. Reference has already been made in these columns to the president's comments on the barriers to the work of the Foundation which have been encountered through restrictions on intellectual freedom in certain countries (see NaTURE, May 21, p. 939).

\section{The Gas Engine Afloat}

IN a paper on "Marine Engineering Problems of To-day" read to the International Conference of Naval Architects and Marine Engineers in June of this year, Mr. Sterry B. Freeman suggests that the time is now ripe for a reconsideration of the gas engine for ship propulsion. On October 11, Mr. J. F. Gibbons read a paper at the Institution of Marine Engineers on "Gas Engines for Small Craft". The author considers only small vessels like tugs, colliers, coasters and trawlers, using gas producers of ordinary type, and the power contemplated lying between 300 and 1,500 h.p. Mr. A. E. L. Chorlton in 1913 outlined a proposal for a gas steam plant of 5,500 brake horsepower suitable for driving a Channel passenger vessel, and took as an example the well-known passenger steamer La Marguerite. The gas engines in this design were to be arranged athwartship and geared to the paddle-shaft. They were assisted in mancuvring by uniflow steam cylinders, the steam being supplied by a waste-heat boiler operating on the gas engine exhausts. In the early stages of development there was no competition by the oil engine, as it had not yet been developed. The ordinary type of marine steam reciprocating engine often operated more economically. In those days, the cost of coal was much less than it is now so there was less urge to reduce its consumption. The question now is very different. Apart from the national advantage of having fuel in the country that does not need to be imported, a great deal of experience has been gained in the design of small producers for use on road vehicles. In an article in Engineering of November 4, it is stated that if the use of gas engines and producers afloat, instead of being tentatively explored by individuals, had been persevered in by established engineering firms, with only a fraction of the financial backing that has been given to Diesel engines, there is little doubt that by now the technical problems would have been commercially solved.

\section{Does the Mocking-Bird Mock?}

THE mocking-bird (Mimus polyglottos) repeats notes used by other birds, and one case at least has been recorded where it was able to do so by the time of its first winter plumage, that is, before it had had much experience in listening to other birds. A suggestion has been made, therefore, that long racial habit in mimicry may have impressed these notes upon the genetic complex of the species, so that the young individual inherited, rather than learned, the adopted song-an acquired character in fact. On the other hand, there is a possibility that the repetition of notes may be due to "parallel ability and adventitious similarity rather than actual and individual mimicry". Another suggestion is made by Loye Miller (The Condor, 40, 216; 1938). He interprets the song as a sequence of motifs, each motif being commonly repeated from three to nine times (making a unit) before a new motif is adopted. An ordinary song employs from thirty-five to fifty of such units. Now these motifs are largely original; rarely do 10 per cent of them resemble the notes of other species of birds, and the resemblances may be fortuitous or mimetic. But the fact that the notes of the California woodpecker or of the shrike are repeated only in places occupied by these birds, suggests some deliberate mimicry. Miller suggests that the mocking-bird is not to be regarded as a plagiarist, but as an artist picking up a suitable stave wherever it may be found to weave into its own roundelay.

\section{Improvement of Child Nutrition}

As appeal has been circulated by the Children's Minimum Council, 72 Horseferry Road, S.W.1, for the improvement of the nutrition of children, and to ensure that no child, by reason of the poverty of its parents, be deprived of at least the minimum of food and other requirements necessary for full health. The Council desires that free milk may be available for all school children, and also midday meals in all schools under local education authorities. Where the expenditure available for food is insufficient, it urges the provision of cheap milk for expectant and nursing mothers and children under school age, and free meals for older children. It is maintained that if the known deficiencies in the national dietary were made good, a revolutionary improvement in the public health would certainly follow. The Council needs an income of at least $£ 1,000$ a year for the continuance and expansion of its work, and subscriptions are invited for this purpose.

\section{Journal of the Czech Astronomical Society}

WITH a delay of only one month during the crushing events of last October, the next issue of $\breve{R} i s e$ Hvézd, the monthly journal of the Czechoslovakian Astronomical Society, has been published under an editorial entitled Začínáme Znovu-"We start again". In this editorial, Dr. Hubert Slouka calls upon all Czech astronomers to unite in working together for the creation of a well-equipped Government observatory, even if only a modest beginning can be made. 
The need for such an observatory is further intensified by the recent ceding to Hungary of the Astrophysical Observatory of Stara Dala. Astronomers and other men and women of science will unite in wishing a happy outcome to this gallant determination to start anew.

\section{Publications of the Carnegie Institution of Washington}

A catalogue of its publications has been issued by the Carnegie Institution of Washington giving a classified list of publications in various branches of science, international law and literature. Most of the books marked in the classified section as out of print are to be found in the libraries throughout the world which have been selected as depositories of the publications of the Institution. A list of these depositories will be sent on application, and a few copies of each publication are reserved for sale at prices which are less than the cost of printing. Price lists or classified lists may be obtained on request and special lists of reprints relating to the work of the Geophysical Laboratory, the Nutrition Laboratory, the Department of Terrestrial Magnetism and the Mount Wilson Observatory can also be obtained. The catalogue also includes an index of authors.

\section{Bibliography of Seismology}

WE have just received vol. 12, No. 18 of this valuable work, and hope that collaborators in many other countries where seismological work is being done will soon come forward. The U.S.S.R., the Balkan States, and South America, to mention only three, and this time even Germany have no representative. It is pleasing to note that Italian papers are represented, and there is a very full list of American publications. It might be suggested that periodical publications of observatories throughout the world be noticed as, in addition to routine readings of seismograms, the more fortunate observatories find time to investigate shocks local to the station. There is a full list of seismological notes from NaTURE.

\section{Mineralogical Society of America : Roebling Medal}

Dr. Waldemar Theodore Schaller, chief mineralogist of the United States Geological Survey, an authority on rare and unusual minerals, has been awarded the Roebling Medal by the Mineralogical Society of America "for meritorious achievement in mineralogy and allied sciences". This Medal, awarded for the first time in 1937, was established in honour of the late Colonel Washington A. Roebling of Trenton, N.J., whose private collection in the field of mineralogy, now forming part of the display at the United States National Museum, contained some 16,000 specimens, many of them very rare, and was one of the most complete in the country. Colonel Roebling's interest in the growth of the Mineralogical Society led him to create an endowment fund to provide a wider scope in mineralogical publication. The medal commemorates his lifelong concern with mineralogy.

\section{Announcements}

THE following elections to the Paris Academy of Sciences have been announced: Prof. W. J. de Haas, professor of physics in the Universitv of Leyden, to be correspondant for the Section of Physics in succession to the late Dr. C.-E. Guillaume; I. Holmgren to be correspondant for the Section of Medicine and Surgery in succession to the late Prof. I. Pavlov; M. Paul Wintrebert, professor of comparative anatomy and histology in the Sorbonne, to be a member of the Section of Anatomy and Zoology in succession to the late F. Mesnil.

Dr. Heinrich RitTer von SRbik, professor of history in the University of Vienna, has been nominated president of the Academy of Sciences of Vienna.

The German Society for the Study of Colloidal Chemistry has awarded its grand annual Laura Leonard prize to Prof. M. Samec of Ljoubljana for his work on the colloidal chemistry of starch.

Dr. Desidor Miskolezy, professor of psychiatry at Szeged, Dr. Roman Adelheim, professor of pathological anatomy in the University of Latvia, Riga, and Prof. Charles Spearman, emeritus professor of psychology in the University of London, have been elected members of the German Academy of Natural Science at Halle.

Dr. H. Morley Fletcher is representing the Royal College of Physicians of London at the opening of the Royal Australasian College of Physicians at Sydney. He presented on its behalf to the new College an illuminated address and a replica of its silver wand or caduceus given by Caius in 1556 .

AT a meeting on October 28 of the international committee for instruction and action for the protection of a civilian community in war, which was set up at Luxembourg on July 4, sub-committees were formed to deal with propaganda, diplomacy, military matters, medical treatment, legal questions, civilian defence and protection of women. The next meeting of the international committee will be held at Luxembourg next January.

The Annual General Meeting of the Association of Women Science Teachers will be held in Bedford College for Women, Regent's Park, London, N.W.1, on January 4-5. On January 4, Prof. Alan Ferguson will deliver a lecture entitled "Some Notes on Eighteenth Century Physics". On January 5, a discussion on "New Methods of Biology Teaching emphasizing Practical Problems with Living Organisms" will be opened by Mrs. Hatfield. Further information can be obtained from M. W. Sutton, 18c Christchurch Road, London, S.W.2.

Erratum.--In the article on "National Parks" in NATURE of December 17, p. 1087, second paragraph, line 18, for " $16,000 \mathrm{ft}$." read " $1,600 \mathrm{ft}$." 